\title{
Women and Igbo cultural tradition: expanding our norms by incorporating esteemed and acceptable values
}

\author{
Jerome Madumelu' ${ }^{1}$ PhD, Amara Egbo ${ }^{2}$, Chukwuma Gideon Okeworo ${ }^{3}$ \\ ${ }^{1,2,3}$ Department of Sociology/ Anthropology, Nnamdi Azikiwe University, Awka, Nigeria
}

\begin{abstract}
This paper underscores the fact that Igbo traditional values should be expanded and incorporated into esteemed and acceptable values. Esteemed values entail women who carved a niche for themselves irrespective of their professions whether formal or informal. This set of women should be allowed to actively participate in certain Igbo "cultural traditions." The formal sector has to do with established institutions while the informal sector has to do with self-thought and self-made institutions. These esteemed values, every other thing being equal, should attract the privilege of active participation in those values socially recognized among the Igbo people. This paper argues that a segment of womenfolk who have distinguished themselves in their various formal and informal sectors should be privileged to perform cultural functions from which they have been excluded for centuries. This study also argues on the incorporation of Igbo cultural values in terms of inclusiveness irrespective of social gender construct. The essence of incorporating the esteemed and acceptable values is to deepen and widen the hold of Igbo cultural values. Those cultural traditions include breaking of kola-nut and performing new yam festival rites, becoming Igwe's among others. This paper adopted a thematic style of literature review which was informed by the topic under study. The existing scholarship in the area under study revolves around the analysis of gender discrimination and comparative studies of gender. It is against this backdrop and the need to bridge the existing gap that makes this study highly imperative. The data employed for this study were gathered from secondary sources.
\end{abstract}

Keywords: Discrimination; Distinguished; Gender; Privileged; Participation 


\section{6th International Conference on New Findings ON HUMANITIES AND SOCIAL SCIENCES}

\section{Introduction:}

20 - 22 August 2021

Dublin, Ireland

This is a gender-specific study. As trendy as this study is, it has not been quite long since serious attention was drawn to the issue of male and female equality in the academic arena. The term issue is applied to this study instead of a problem because the latter has a solution but the former does not. Seeking a hundred percent solution to gender issues is likened to tabulating a liquid substance. Such an idea of perfect equality between men and women as well as other social constructs was driven by Karl Marx when he devised a utopian ideal of a classless society which will be visualized when the dialectical war between classes (bourgeois and the proletariat) comes to an end. This research is focused on bridging the widening gap between the warring classes, men and women of Igbo extraction by advocating for a systematic, innovative, and planned inclusion of women achievers into the mainstream of Igbo cultural tradition. By this designed inclusion, it is hoped that the incorporation of women into esteemed and acceptable Igbo cultural values, will lead to an expanded and stronger hold of Igbo culture on every fabric of Igbo tradition. As more women are added to be purveyors of Igbo traditional cultural values, the more the tradition expands. This expandability of traditional hold on Igbo culture by incorporation of women who have carved a niche for themselves will widen the horizon of Igbo cultural tradition.

\section{Statement of the Problem}

Globally, gender is viewed as a social construct that wields a pervasive influence in society. Modern trends show that being born a girl or a boy has implications that go considerably beyond chromosomal, hormonal, and genital differences (Ruble, Martin, \& Berenbaum, 2007). It is therefore not anatomical or biological but contextually manipulated and operates differently in different facets of human structure. Being gendered especially of the female species denotes a level of limitedness in the social strata of the world. Limited knowledge of how to design gender transformative research and the long-term engagement essential for tackling structural disadvantages posits a great difficulty (Sverdlik, 2021). Conventional heteronormative beliefs regarding gender roles, gender identity, and sexual orientation are challenged individually and likewise by the experiences of many transgender individuals (Nagoshi, Brzuzu \& Terrell, 2012). A critical review of the extant literature concerning the present problem understudy discovered that most of the work done on the subject matter was merely centered on gender discrimination, comparative or merely asking for the recognition of the roles of women (Anah, Okere, \& Britton, 2017). As such, this paper is highly imperative to address the existing gap. However, there is no study of this magnitude that has been done in the area under study. That is why this paper is apt and timely.

\section{Objective}

This is meant to stimulate ideas and challenge Igbo women who have attained the esteemed values spoken of above to take their destiny into their hands. Also, advocating for those women who have distinguished themselves by way of achievements in their different endeavors to have the permission to perform certain denied privileges or positions attainable 


\section{6th International Conference on New Findings ON HUMANITIES AND SOCIAL SCIENCES}

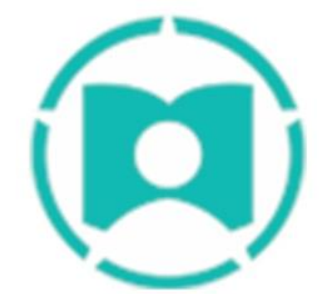

20 - 22 August 2021

Dublin, Ireland

only by men in the Igbo tradition like the breaking of kola-nut, performing new yam festival rites, and becoming Igwes among other things. The research appeals to men of our age to be responsive to the reality of the expandable nature of our cultural tradition. Appropriating the fact that tradition grows and changes would present the men of this age as being socially creative and proactive in narrowing down the deplorable gap of sexism and opening up windows of opportunity for the girl child to aspire to. By allowing womenfolk to enjoy the privilege of entitlements based on their accomplishments, it is deepening the hold of the Igbo culture/tradition and widening its horizon in all that affect the Igbo people.

\section{Significance and Scope of this Study}

This study is meant to fill, to some comforting level, the deep valley of subjugated deprivation created by the erosion of sexism over the centuries. It has both theoretical and practical imports. Theoretically, it uses social constructivism and stratification to demonstrate that male domination can be ameliorated. Practically, it demonstrates that reality is manmade and can become adaptive. When society accepts the fact that reality is manufactured and not something unchangeable, it assures cohesiveness where the "veil of ignorance" which according to John Rawls is where "equity, justice and fairness reign" (Peter, 2006). The scope of the study is limited to women, who through their efforts have made marks for themselves and become the pride of the Igbo society. This paper aims to mainstream such ladies into participating in many privileges offered by the Igbo society, and above all widen and deepen the cultural values. Again the study is not presumptuous of the seeming impossibility of having a classless society or a society without stratification.

\section{Conceptual Clarification}

Globally, gender is taken as a social construct that wields a pervasive influence in society. It operates differently in different facets of human structure. Many researchers acknowledged the numerous practical and conceptual challenges when defining the term gender. Main concerns border on the complexity of analyzing gender and other characteristics of difference; because male and female experiences are different based on their divergent roles in society. In addition, difficulty arising from gender analysis is based on the fact that data for men and women are collected as dis-aggregated and women's experience is different from men's experience because they are not assigned the same role often. For example, in an interview with some transgender persons, Nagoshi et al. (2012), discovered that gender roles as a social construct are well understood by transgender persons but they (transgender persons) viewed gender identity as being more fluid, "compared to essentialist, binary, heteronormative ideas about gender"(p. 405).

According to Ruble et al. (2007), modern trends show that being born a girl or a boy has implications that go considerably beyond chromosomal, hormonal, and genital differences. In 2003, UNESCO described gender as referring to the roles, responsibilities, and even expectations created in our families, societies, and in our culture. John Money in 1973 first 


\section{6th International Conference on New Findings On HUMANITIES AND SOCIAL SCIENCES}

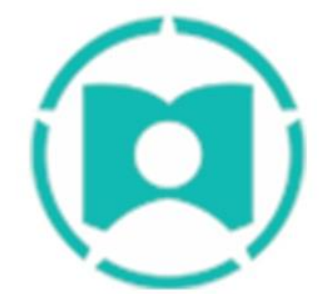

20 - 22 August 2021

Dublin, Ireland

published online in 2017, was the first to make use of the word "gender role" with the assertion that gender is revealed by what one says or does. Both gender roles and expectations are learned. In social analysis, the concept of gender shows how women's subordination (or men's domination) is socially constructed. This implies that subordination can be changed or ended. It is not biologically fixed or predetermined forever. Gender inequity and all other challenges arising from it are not easy to solve. Even in cases where some legislations have been made regarding gender equality, the implementation is more on the pages of newspaper and media channels than in real life. For example, Nigeria is a signatory to most of the world treaties relating to women such as the United Nations Convention on the Elimination of All Forms of Discrimination against Women, 1979 (CEDAW) and the Beijing Declaration and the Platform for Action, 1995 which advocated for equality of women in all spheres of life but it is all on paper.It must be recognized that since the 1920s, women's advancement in the corporate world has taken significant strides. Yet, we have a long way to go as far as respectful recognition of women's roles and contributions to society are concerned. The division of roles along gender lines places women in an underprivileged position in terms of power, prestige, and wealth. This paper argues that gender role differentiation negatively restricts the life chances of women thus, affecting their mobility patterns. However, changing institutional arrangements tend to alter social mobility in favor of women in contemporary Nigerian society. Changing the institutional arrangements to benefit women achievers is the focus of this paper.

\section{African Perspective on gender}

When considering women in the African culture, there seems to be disequilibrium between the roles men and women play in society. Women are considered "inferior" to men and this is noticeable in the kind of activities that are centered on women. The reason women are placed on such a low pedestal is because of the patriarchal nature of the African society as most authors, especially the colonial one imply. Writing about gender and its inherent inequality from patriarchal perspectives, Clement (2013) created an ugly picture about the condition of women in Nigerian society. His ideas about women reflect the quotation made by president Buhari in Germany, 2016 when he said that a woman's place belongs to the kitchen and the other room. When a president can degrade women publicly and internationally in a public briefing, imagine how women in such a country are treated. Using a social dominance theory in qualitative research, Adisa, Mordi \& Iwowo, (2021) supported the idea that women's position in Nigeria is that of subjugation. However, chronology shows that this rigid division of roles along gender lines was firmly sown by the colonial intervention.In the words of Isike \& Uzodike, (2011), "...the positive human factor values which defined womanhood in precolonial Africa have been corrupted over time by the colonial interruption of Africa's sociocultural existence leading to the marginalization, tokenization, and de-feminization of women in political and peace processes in post-colonial Africa" (p.35). In the language of Okonjo (1976), as quoted by Madumelu (2014), Africans during this period practiced what Okonjo described as the dual-sex political system. The practice of this system was very pronounced among the Igbo people who live west of Niger. Thus Okonjo 1976, Nzegwu, 2001, opined 


\section{6th International Conference on New Findings ON HUMANITIES AND SOCIAL SCIENCES}

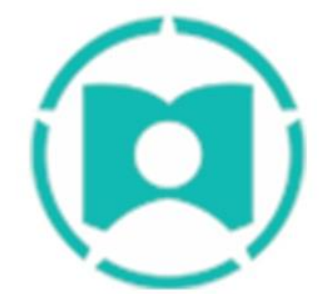

20 - 22 August 2021

Dublin, Ireland

that the dual-sex system involves a kind of small government ideology where "each sex generally managed its affairs and had its kinship institutions, age grades and secret and title societies" (p.47). The dual-sex political system suggests that among the Igbo people of Nigeria, women are not slaves (Okonjo, 1976)). This de-emphasizes the fact of male domination over women as western ideology purports. The trending ideas about gender stereotypes as we know them today in human society were not present in the past. Some Nigerian feminists point to the fact that African culture and tradition fell apart with the invasion of western ideas (Amadiume, 1998, Nzegwu, 2001, Oyewumi, 2002). According to Amadiume (1998),

The fact that biological sex did not always correspond to ideological gender meant that women could play roles usually monopolized by men, or be classified as 'males' in terms of power and authority over others. As such roles were not rigidly masculinized or feminized; no stigma was attached to breaking gender roles. Furthermore, the presence of an all-embracing goddess-focused religion favored the acceptance of women in statutes and the role of authority and power (p.185).

Isike et al. (2011) supported the above quotation when they said: "Masculinities are fluid and dynamic, and we cannot speak of a single universal African patriarchy. Over time, different forms of patriarchies existed in different pre-colonial African societies" (p.34). This is why Madumelu (2014) opined that patriarchy is not everywhere practiced the same and he rightly described the practice of patriarchy as contextually manipulated. Unfortunately, with the Western interaction, the center could no longer hold in the words of Achebe's Things Fall Apart. Contact with the West changed the dynamics that pushed women outside the periphery of power and hierarchy. Amadiume (1998) articulated the change thus: In contrast, Western culture and the Christian religion, brought by colonialism, carried rigid gender ideologies, which aided and supported the exclusion of women from the power hierarchy, whether in government or the church in modern society. This rigid gender system meant that roles are strictly masculinized or feminized; breaking gender rules, therefore, carries a stigma (p. 185). A stigma as suggested by the above quotation touches on every aspect of human endeavor as far as the male-female relationship is concerned. Women bore the brunt aspect of unequal and unjust relationships. Inequity is a creation of human society or what is in our case called social construction. Much of how we choose to live is very much an enactment of our cultural traditions (Cheryl de la Rey, 1992). Our cultural tradition posits or is of the view that men are dominant and should be responsible for how the society operates or how the society works (inclusive of how the women behave). The ideology of male domination having a field day in dictating what is good for themselves as well as what is good for women without negotiation is very risky. Once this idea is not challenged, it could become "amplified over time and institutionalized into permanent lines of social, economic, and political cleavage" (Schneider \& Ingram, 2004). This is what has been obtainable in the Igbo tradition relating to men and women in certain cultural traditions with no connotative or denotative implications: the ideology of breaking kola-nuts, masquerade institutions, and other festival celebrations and titles among the Igbo people. Ritual practices involved in the breaking of kola-nuts, initiation 


\section{6th International Conference on New Findings ON HUMANITIES AND SOCIAL SCIENCES}

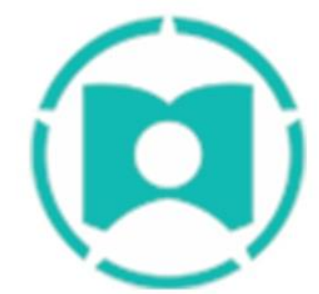

20 - 22 August 2021

Dublin, Ireland

into the cult of masquerade, and other social festivities such as new yam festivals are discriminatory of women. Omeje \& Jacob (2019) depicts this discriminatory tendency as childish since no woman is denied kola-nut when it is broken and shared eventually. Furthermore, they argued that women do break the kola-nut when they gather in their cultural groupings of Umuada (a council of women) where no man has a saying. Most of the abovementioned social activities are said to be male-oriented. Some people believe that women should not touch Kola-nut because of its high degree of sanctity as if men are holier than women. Others argue that the building of a prohibitive castle around kola-nut against women is simply to epitomize male headship by anointing or boasting his ego.

In the words of Omeje \& Jacob (2019) "... what one witness is some ideological insubstantial practices which tended to point to women that the kola is a thing for the men to handle even if the women are to partake in the eating. (p. Not given)In the above quotation, we see lots of flimsy reasons given to prevent women from enjoying the social privileges conferred by the society on her citizens for positive contributions to social development and growth. On the other hand, title taking such as being the Igwe of a town is another area where women have not been allowed to partake. However, there is a beautiful story by Ezekwem (2021) in her review of The Female King of Colonial Nigeria: Ahebi Ugbabe. In this story, Ezekwem reported how an Enugu-Ezike local girl, Ahebi Ugbabe, of no consequence in the late 19th century, became a headman, rose to a warrant chief and was finally elevated to the position of a king. Being a multi-linguist, which she used to help the colonial masters, endeared her to the British Forces who in appreciation for her support made it possible for her to rise to different positions mentioned above. This is a "feat that was contrary to the British policy of female political exclusion in colonial Nigeria. As king, she performed female masculinities and superseded all existing male political hierarchy and authority"(review no. 1393). It is quite interesting to know thatqualification and capability attracted the attention of Colonial forces to recognize the ability of the young Ahebi to the extent of elevating her to the post of kingship. Unfortunately, the past and present generation has refused to adopt the colonial positive recognition of talent even with the social and economic implications of having women in power. In the recent past, for example, the effectiveness and inclusiveness found in handling the Covid-19 pandemic responses were outstanding in countries where women were in charge. Some of the countries where women leaders performed marvelously well in containing the spread of the virus are Denmark, Ethiopia, Germany, Finland, Iceland New Zealand among others. In such countries, lower Covid-19 death rates were recorded. The big question is: why are women under-represented in such other fields as education, economics, and social affairs, and why are women achievers restricted from enjoying the social privileges which are hitherto male-dominated and enjoyed? Metaphorically, Nora Frenkiel in Adweek in March 1984, quoted by Schwanke (2013), said that lots of "glass ceiling" constitute serious barriers for women to get to the position of directorship, governance, executive leadership among others. A lot of women are stuck in midmanagement positions and need to navigate through complicated labyrinths to get to the highest positions (Schwanke, 2013). 


\section{6th International Conference on New Findings ON HUMANITIES AND SOCIAL SCIENCES}

\section{Tradition and Society:}

With the advent of modernity, the tradition was seen as consisting of things on their way out. When the evolutionary theory was in vogue in the mid-nineteenth century, the tradition was doomed by progress, thought to be an accidental survival of an earlier age, a carrier of backwardness, such as feudalism and superstition, and most ominously, aspects or ways of life which, it was hoped, like the major diseases, would give way to progress and be destined for extinction. European anthropologists and archeologists perceive tradition in the age of social science as the vestiges of earlier forms of human society (Grabum, 2006). People in those days thought that tradition in situations of change, were to be continued to be handed on, thought about, preserved, and not lost. It is seen as a reservoir, strength to draw upon, a source of historically defined identity, and a source of safety, specialness, or difference (Grabum, 2006). Tradition is not just on its way out but rather changes with the changing times.

On the other hand, most social theorists, despite their different views, are all concerned with the question of social unity or order. Despite the divergent views of theorists on society, each society enacts its tradition. As society changes, the tradition does the same. Karl Marx (1818 - 1883), as summarized in New Catholic Encyclopedia (1967), captures well the reasons for the changing society, and the consequences of such changes when he defined society thus:

"...a dialectical process of warring classes wherein economic factors determine the structure and development (p. 391). The warring classes here are men and women - gender classism. And ours is to devise ways to reduce the spate of discrimination between men and women in matters of social privileges which directly or indirectly is fueled by the struggle for economic power.

\section{Men's fear or Respect for women achievers: Reasons for inclusion.}

A research work using oral interrogation, published and unpublished works, ascertained how the issues of fear and respect for women gave rise to some cultural practices in Igboland with examples from specific Igbo communities. Opata and colleagues opined that in some communities' women were behind the origin of festivities but because of the dialectical war between men and women, the latter was suppressed and edged out of the limelight. The birth of certain cultural institutions by women in some communities is always ignored. For example, the institution of Odo masquerades which were founded by women in Ukana but were later displaced for economic reasons, and the history of Onunu in Itchi where women were noted to have been the first to acquire land and start the land business, the history of which was later misinterpreted to favor men denying women their ingenuity in land acquisition. This research is meant to ensure that the "efforts of Igbo heroines past are not interred with their bones and to mitigate the spate of denigration of women," (Opata et al. 2021 , p. 201). The non-recognition of women's contribution to the state building is it based on fear of women or respect for them in the evolution of festivals and some customary practices? Mentioning McFarland (1987) and Gurson (2011), Opata and colleagues defined 


\section{6th International Conference on New Findings ON HUMANITIES AND SOCIAL SCIENCES}

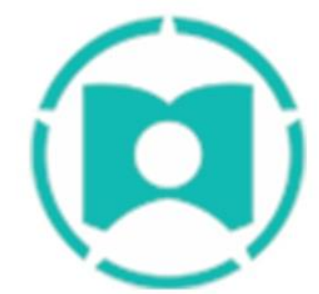

20 - 22 August 2021

Dublin, Ireland

fear thus, respectively: "...a motivational condition aroused by specific stimuli that give rise to self-protective actions or escape" and as an "emotion that plays an important part in our lives and pre-programmed into all animals and people as an instinctual response to potential dangers" (Opata et al. p. 204). By edging women out of economic possibilities, men tried to assuage their fear of being overtaken, and indirectly or directly men's fear stops engagement and therefore growth. Fear by implication is contemptible, and a sign of cowardice. Situated well in this work, fear means all those "panicky measures adopted by the men to dislodge women from the scheme of things and as well deny them of their due place in history to place themselves strategically at the commanding height of events in their polity" (p. 204). There seems to be a kind of conspiracy not to acknowledge the contributions of women to societal development.

\section{Theoretical Framework:}

Social Constructionism and Social Stratification help explain the tension arising from the hierarchical arrangement of individuals or group of individuals into divisions of power and wealth within a society This idea of social constructivism was first propounded by George Herbert Mead (1934) in his famous work "Mind, Self and Society" which was published posthumously in 1934 by Derrida in his work "Structure, Sign, and Play" which was also printed by Macksey and Donato (1970) as mentioned in Wikipedia. Friedrich Nietzsche said it all about Social Constructionism when he said that "Facts do not exist, only interpretations." Michel de Montaigne similarly said that we need to interpret interpretations more than we interpret things (Wikipedia). Social Constructionism and Social Stratification theoretical frameworks address the tension inherent in gender construction and the arbitrariness of assigning roles to males and females and the presentation of such construction and arbitrariness as natural. Drawn from Free Online Dictionary for Students, Social Constructionism can be defined as a theory that says that all reality and meaning is subjective and created through dynamic interaction with other individuals and groups. It operates on the assumption that reality is constructed through human activity. This theory states that our ways of understanding the world do not come from objective reality but other people both past and present. We are born into a world where the conceptual frameworks and categories used by the people in our culture already exist (Burr, 2015). Constructionism is focused on relations and sustains the individual's role in the social construction of realities. Meaning, therefore, is a shared reality (Galbin, 2014). Role assignment is not the issue but the standard for such assignment and whether the standard for role assignment provides systematically equal opportunity for males and females in the society. On the other hand, stratification is a process of ranking statuses that are found in all societies. This inequality of status is a remarkable feature of Social Stratification. People on the top statuses have more power, prestige, and privileges in comparison to those who are placed lower, therein. Society is stratified into social classes based on an individual's socioeconomic status, gender, and race. Inequality is the result of stratification when the limited resources, opportunities, and privileges are allotted based on an individual's position in the social hierarchy. Men are 


\section{6th International Conference on New Findings ON HUMANITIES AND SOCIAL SCIENCES}

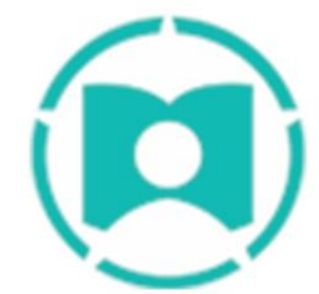

20 - 22 August 2021

Dublin, Ireland

socially taken to be superior to women and therefore they are privileged more than their female counterparts (Shah, 2018). It is, therefore, more relevant that Social Stratification theory is best situated for the way men treat women in Igbo society. Since the class war between men and women is an open system and not a close one, this paper strongly advocates that more women should be allowed to enjoy the social privilege which their male counterparts enjoy in such things as breaking the kola-nut, enjoying the title as Igwes, inheriting lands and officiating at some ritual festivities.

\section{Methodology:}

The study adopted a qualitative method in carrying out its investigation. The data employed for the study were gathered from secondary sources. As such, data used for this study were collected from public libraries as well as private libraries of some of colleagues and associates within and outside the country. Besides, the study also made use of internet materials wherein relevant articles were carefully gathered. The study utilized both content analysis and trendy analytical techniques for the analysis of data. Hence, the information employed for analysis in the study was carefully extracted from logical chains of evidence presented in journal papers, conference papers, periodic papers, edited books and documentary materials among others.

\section{Findings:}

In this research, it is discovered that women are marginalized and denied social prestigious privileges because those in power think and treat the social systems in operation as if they are all closed systems. By close system, I mean the system of operation that hardly admits changes, unlike the open system. Again, this research is conducted at a time in Nigeria and particularly the Igboland where corruption has eaten into every fabric of the society. Qualified people who serve the interest of the people and understand the invaluable potency of including deserving and entitled women in the social life of the community are neither elected nor appointed. Innovative or creative people are not in power because of corruption. Women achievers are feared as the 'out-group members dangerous to be incorporated otherwise women will deserve also of the social benefit entitled to men alone for ages. In the 21 st century, some privileged men act as carriers of backwardness believing in superstition and insubstantial ideologies attributable to our ancestors yet without any evidence to support their claims. For example, that women should not be involved in kola-nut breaking because some spirits do not like women is an unfounded assertion.

\section{Analysis:}

The literature review reveals that most writers influenced by western ideologies are more likely to believe that African women are pushed to the periphery of power. Both international and local publications where super policies/treaties that favor women are prescribed look good only on ink and paper. Such policies lack concrete evidence in the social treatment of women, especially, in the African Nigerian Igbo settings. In matters socio-cultural, where the 


\section{6th International Conference on New Findings ON HUMANITIES AND SOCIAL SCIENCES}

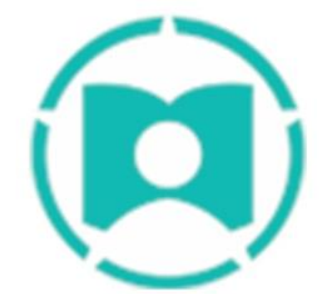

20 - 22 August 2021

Dublin, Ireland

society recognizes and allots some privileges to men achievers, women who have equally contributed to the society are hardly recognized as deserving and entitled. There is gender classism of what Karl Marx called a 'dialectical warring class' between men and women and it is all about economic control. It is all about the fact that women are to be seen and not heard; for the earth belongs to men and women are visitors. This type of mindset was obtained in the Stone Age but it is still very much alive in our time. It seems that those who direct the affairs of this generation are mentally anachronistic. Also, based on the fact that we live in an age where corruption reigns, meritocracy is offered on the altar of nepotism and abysmal ineptitude enthroned. All we need are traditional kings and chiefs in positions of power who can order and stabilize society with their knowledge and skills. Kings and Chiefs who understand the importance of inclusiveness and the tradition of our forefathers with qualified education should be elected. Amadiume, in a manner of Chinua Achebe, argues that there are matters that are still outstanding in the fight for women's liberation. She expressed that such issues can be resolved by the use of internal logic in the examination of the traditional practices of gender and to argue from within. "Invariably, she argues, "despite internal contradictions in Igbo traditional practices of gender empowerment and sociocultural pragmatism, achievements in women's rights and freedom are not attributable to the postcolonial or simply the "modern," as there remain deep and continuous traditional histories at play in these encounters"(p.119).

\section{Conclusion:}

This paper underscores the fact that Igbo traditional values should be expanded and incorporated into esteemed and acceptable values. Esteemed values entail women who carved a niche for themselves irrespective of their professions whether formal or informal. The literature review reveals that before the invasion of the colonial masters, Igbo culture or society was more sensitive to the plight of their women especially those who have carved a niche for themselves. So many international treaties had been made regarding the best way to get the womenfolk to the mainstream of politics, economy, and social life of the world community. For example, the World Conference on Women, 1995, which focused on Action and Equality, Development and Peace and was convened by the United Nations, unfortunately, policies made out of that conference and many others have never been implemented in Nigeria. Also internationally and locally, the men in power have not followed up on so many declarations meant to incorporate women into the mainstream of social life. In this way, those women who have contributed much to social development are yet to be treated as deserving and entitled to the values and privileges which their communities confer on men who have contributed as well to the wellbeing of the common good. This paper, therefore, posits a challenge to those in positions of power who can make the life of enterprising women rewarding and enjoyable socially. The racial discrimination and the great lesson thereof, in America, as articulated by Schneider and Ingram (2004) can be applied to the women problem exacerbated by the colonial invasion in Igbo land. Abuse of power need to be questioned as Schneider and Ingram rightly put it thus: 


\title{
6th International Conference on New Findings ON HUMANITIES AND SOCIAL SCIENCES
}

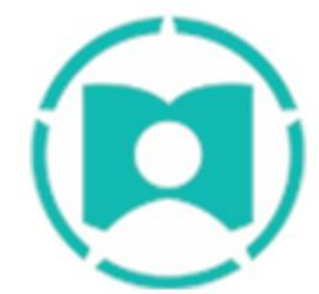

20 - 22 August 2021

Dublin, Ireland

\begin{abstract}
Public policy... is marked by a contradiction between the ideal of equality and the reality of an underclass of marginalized and disadvantaged people who are widely viewed as undeserving and incapable. Deserving and Entitled provides a close inspection of many different policy arenas, showing how the use of power and the manipulation of images have made it appear both natural and appropriate that some target populations benefit from the policy, while others do not. These social constructions of deservedness and entitlement, unless challenged, become amplified over time and institutionalized into permanent lines of social, economic, and political cleavage. The contributors here express concern that too often public policy sends messages harmful to democracy and contributes significantly to the pattern of uneven political participation (p.2).
\end{abstract}

The above quotation summarized well the effort of this paper targeted at powers that reject to incorporate respectfully enterprising women into Igbo privileged social entitlements. The apparent contradiction in the practice of equity between the two sexes, the marginalization, and subjugation, and the consequent justification of this undeserving marginalization process is a great concern.

\section{Strategies for incorporating women in the mainstream of Igbo tradition}

1). All policies made for women's liberation, both local and international that are in sync with the context of women in Igboland, must be made part of the State Constitution to have the force of law and be implemented. Otherwise, it will be playing to the gallery to be a signatory to all those treaties without any of them having the force of law.

2) Educated traditional rulers, serving as calabash of wisdom in matters socio-cultural, must be preferable to those who are rich but lacking in the knowledge of tradition and culture. Experience has shown that stability and unity of society is better assured by knowledgeable people. Such people are more likely to incorporate women achievers to expand and strengthen the Igbo traditional culture.

3). Women who have distinguished themselves in their various professions either formal or informal sector should be given equal right with the male counter-part to participate in Igbo cultural tradition.

\section{References:}

1. Adisa, T. A., Mordi, C.,\& Iwowo, S. V. (2020). Social dominance, hypermasculinity, and career barriers in Nigeria. Retrieved on 15/07/2021 from https://onlinelibrary.wiley.com/doi/full/10.1111/gwao.12537

2. Amadiume, I. (2015). Of kola nuts, taboos, leadership, women's rights, and freedom: New challenges from Chinua Achebe's There was a Country: A personal history of Biafra. Journal of West African History, vol. 1(2), pp.119 -146.

3. Anah, C.K.,\& Okere, M.C. (2019). The social construction of gender in traditional Igbo society: A comparative study of the language used as socialization in John Munonyes's the Only Son and flora Nwapa's 
4. Efuruhttps://www.researchgate.net/publication/333582943_The_social_construction of_gender_in_traditional_Igbo_societies

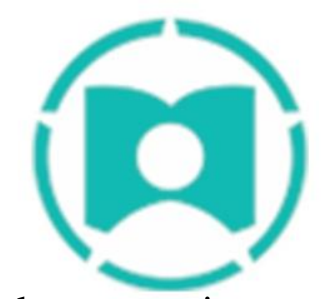

$20-22$ August $\overline{2} 021$

5. Apleni, L. (2012). Women's role in the transformation of South Africa, Dodetionedeland the 06/22/2021 from https://www.google.com/search?

6. Bennett, S. E.,\& Bennett, L. L. M (1992). From Traditional to Modern conceptions of gender equality in Politics: Gradual change and lingering doubts. Western Political Quarterly, vol. 45. Pp $93-111$

7. Blackstone, Amy. 2003. Gender Roles and Society in Human Ecology: An Encyclopedia of Children, Families, Communities, and Environments, edited by Julia R. Miller, Richard M. Lerner, and Lawrence B. Schiamberg. Santa Barbara, CA: ABC-CLIO, pp. 335-338

8. Britton, D. M. (2017). Beyond the chilly climate: The Salience of Gender in Women's Academic Careers. Gender and Society, vol. 31 (1), pp. 5 - 27

9. Cheryl de la Rey, (1992). "Culture, Tradition, and Gender: let's talk about it" in Agenda: Empowering women for gender equity, no.13. pp. 78 - 86 https://www.jstor.org/stable/4065618

10. Chidume, C.G., Osisioma, U. S.,\& Echem, S.O. (2015). The symbolism of kola-nut in Igbo Cosmology: A re-examination. International Journal of Research in Humanities and Social Studies, vol. 2(8), pp. 51 - 56. Retrieved on the 25/06/2021 from https://www.google.com/search?

11. Clement, C. (2013). Patriarchy and gender inequality in Nigeria: The way forward. European Scientific Journal, vol. 9, no. 17

12. Connell, R. W (2005). Change among the Gatekeepers: Men, Masculinities, and Gender Equality in the Global Arena vol 30(3) pp.1801 -1825

13. Ezekwem, O. (2021). Review of The Female King of Colonial Nigeria: Ahebi Ugbabe, (review no. 1393). Retrieved on 26/06/2021 from https://reviews.history.ac.uk/review/1393

14. Galbin, A (2014). An Introduction to Social Constructionism. Retrieved on 22/07/2021 from https://www.researchgate.net/publication/283547838

15. Grabum, N. H.H. (2006). What is Tradition? Museum of Anthropology, 24(2) pp. 6 11

http://www.unesco.org/new/fileadmin/MULTIMEDIA/HQ/BSP/GENDER/PDF/1.\%20Baseli ne $\% 20$ Definitions $\% 20$ of $\% 20 \mathrm{key} \% 20$ gender-related\%20concepts.pdf

https://www.researchgate.net/publication/330449351_The_Symbolism_of_Kolanut_in_Igbo_ Cosmology_A_Re-Examination

16. Ifemeje, C. I.,\& Umejiaku, N. (2014). Discriminatory Cultural Practices and Women's Rights among the Igbo of South-East Nigeria: A Critique. Journal of Law, Policy, and Globalization, vol. 25. Retrieved on the 26/07/21 from https://core.ac.uk/download/pdf/234649863.pdf

17. Isike, C.,\& Uzodike, U.O. (2011). Towards an indigenous model of conflict resolution: reinventing women's role as traditional peacebuilders in neo-colonial Africa. Retrieved on the 24/07/2021from https://www.ajol.info/index.php/ajcr/article/download/69832/57912/0m

18. Madumelu, J. (2014). Widowhood in two Igbo Communities of Nigeria: contextual manipulation of patriarchy. U.S.A: ProQuest

19. Money, J. (2017). Gender role, Gender identity, Core gender identity: Usage and definition of terms. 


\section{6th International Conference on New Findings On HUMANITIES AND SOCIAL SCIENCES}

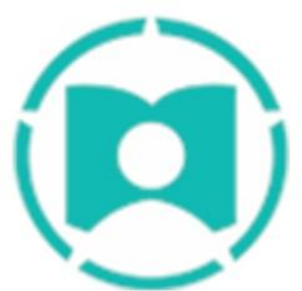

20. Nagoshi, J. L., Brzuzy, S.,\&Terrell, H.K. (2012). Deconstructing the complex

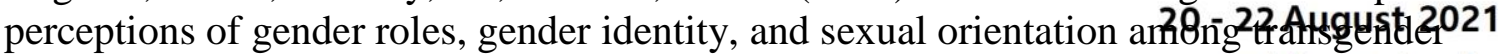
individuals. Journal of Feminism and Psychology, vol.Dub\$i, Ireland https://journals.sagepub.com/doi/abs/10.1177/0959353512461929

21. Nash, J. (2016). Gender roles in modern society. Retrieved on 22/07/2021 from https://www.oneworldeducation.org/our-students-writing/gender-roles-in-modernsociety/

22. Nzegwu, N. (1995). Recovering Igbo Traditions: A case for indigenous Women's Organizations in Development. Retrieved on the 25/06/2021 from https://oxford.universitypressscholarship.com/view/10.1093/0198289642.001.0001/ac prof-9780198289647-chapter-21

23. Ojukwu, E.V.,\& Ibekwe, E. U. (2020). Cultural suppression of female gender in Nigeria: Implications of Igbo females songs. Journal of Music and Dance, Vol. 10 (1). Pp. $1-13$

24. Omadjohwoefe, O.S. (2017). Gender role differentiation and social mobility of women in Nigeria, Journal of Social Sciences; Retrieved on 3rd July 2021, https://www.tandfonline.com/doi/abs/10.1080/09718923.2011.11892907

25. Omeje, P. U., \& Jacob, U.H. (2019). Masquerades and Kola-nut culture in Igboland: Continuity and change in the Igbo socio-cultural practices. Afro Asian Journal of Social Sciences, vol. X, No. III.

26. Opata, Christian C., Apeh, Apex A., Odoja, Asogw a S., and Emmanuel, Alaku. (2021). Women and evolution of cultural practices among the Igbo of Nigeria. Journal of International Women's Studies, vol. 22(1), 201 - 214. Retrieved on 22/06/2021 https://vc.bridgew.edu/cgi/viewcontent.cgi?article=2368\&context=jiws

27. Osei-Nyame, K. (1999). Chinua Achebe Writing Culture: Representations of Gender and Tradition in "Things Fall Apart." Summer, 1999. Vol. 30 (2), pp. 148 - 164. Retrieved on 22/06/2021 https://www.jstor.org/stable/3820564

28. Peter, (2006). Beyond the veil of ignorance. Retrieved from http://onphilosophy.wordpress.com/2006/05/05/beyond-the-veil-of-ignorance/

Retrieved on 14/06/2021

29. Ruble, D. N., Martin, C.L.,\& Berenbaum, S. A. (2007). Gender Development in Handbook of Child Psychology, Vol. 111 Retrieved on the 18/06/2021 https://onlinelibrary.wiley.com/doi/epdf/10.1002/9780470147658.chpsy0314

30. Schneider, A. L.,\& Ingram, H. M. (2004). Deserving and Entitled: Social Construction and Public Policy (ed.). U. S.A

31. Schwanke, Dee-Ann. (2013). Barriers for Women to positions of power: How societal and corporate structures, perceptions of leadership and discrimination restrict women's advancement to authority. Earth Common Journal, vol. 3(2), p. 234

32. Sverdlik, A. (2021). Gender and Intersectionality in action research. International Institute for Environment and Development (IIED) pp. 1-2.

33. Ukpokolo, C. (2011). Gender, symbols and traditional peacemaking among the Nanka-Igbo of south-eastern Nigeria. Journal of Human Affairs, vol. 21 (2). Retrieved on the 28/07/21from http://yadda.icm.edu.pl/yadda/element/bwmeta1.element.doi-10_2478_s13374011-0018-4

34. UNESCO, (2003). UNESCO's gender mainstreaming implementation framework: Baseline definitions of key concepts and terms. Retrieved on 18/06/2021 from 


\section{6th International Conference on New Findings ON}

\section{HUMANITIES AND SOCIAL SCIENCES}

https://www.scirp.org/(S(i43dyn45teexjx455qlt3d2q))/reference/ReferencesPapers.as

px?ReferenceID $=959248$

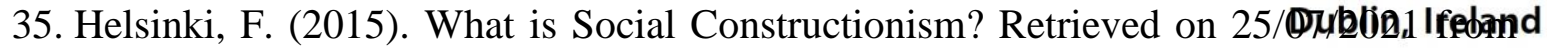
https://courses.helsinki.fi/sites/default/files/coursematerial/4520830/Burr_2015_social_constructionism_Chp_1.pdf

36. Wikipedia: Free Encyclopedia: Social Constructionism. Retrieved on 29/08/2021from https://en.wikipedia.org/wiki/Social_constructionism

37. Khawas, A. (2021). Social Stratification, Retrieved on 30/08/2021 from https://www.iilsindia.com/study-material/985681_1616386342.pdf

38. Shah, S. (2018). Social Stratification: Meaning, Origin, Development and other Details. Retrieved on the 30/08/2021 from https://www.sociologydiscussion.com/social-stratification/social-stratificationmeaning-origin-development-and-other-details/2260 